\title{
Simulations of maglev EDS performance with detailed numerical models
}

V. M. Amoskov ${ }^{1}$, D. N. Arslanova ${ }^{1}$, A. M. Bazarov ${ }^{1}$, A. V. Belov ${ }^{1}$, V. A. Belyakov ${ }^{1,2}$, A. A. Firsov ${ }^{1}$, E. I. Gapionok ${ }^{1}$, M. V. Kaparkova ${ }^{1}$, V. P. Kukhtin ${ }^{1}$, E. A. Lamzin ${ }^{1}$, M. S. Larionov ${ }^{1}$, A. V. Mizintzev ${ }^{3}$, V. M. Mikhailov ${ }^{1}, A$. N. Nezhentzev ${ }^{1}$, D. A. Ovsyannikov $^{2}$, A. D. Ovsyannikov ${ }^{2}$, I. Yu. Rodin ${ }^{1}$, N. A. Shatil ${ }^{1}$, S. E. Sytchevsky ${ }^{1,2}$, V. N. Vasiliev ${ }^{1}$, M. Yu. Zenkevich ${ }^{4}$

1 JSC "NIIEFA", 3, Doroga na Metallostroy, St. Petersburg, 196641, Russian Federation

2 St. Petersburg State University, 7-9, Universitetskaya nab., St. Petersburg, 199034, Russian Federation

3 NIIEFA-ENERGO Ltd, 5, Doroga na Metallostroy, St. Petersburg, 196641, Russian Federation

4 General A. Khrulyov Academy of Rear Services of Armed Forces, 8, Makarov nab., St. Petersburg, 199034, Russian Federation

For citation: Amoskov V. M., Arslanova D. N., Bazarov A. M., Belov A. V., Belyakov V. A., Firsov A. A., Gapionok E. I. , Kaparkova M. V., Kukhtin V. P., Lamzin E. A., Larionov M. S., Mizintzev A. V., Mikhailov V. M., Nezhentzev A. N., Ovsyannikov D. A., Ovsyannikov A. D., Rodin I. Yu., Shatil N. A., Sytchevsky S. E., Vasiliev V. N., Zenkevich M. Yu. Simulations of maglev EDS performance with detailed numerical models. Vestnik of Saint Petersburg University. Applied Mathematics. Computer Science. Control Processes, 2018, vol. 14, iss. 4, pp. 286-301. https://doi.org/10.21638/11702/spbu10.2018.402

This article finalizes the feasibility analysis of electrodynamic suspension systems (EDS) for magnetically levitated (maglev) transport. Parametric simulations for a range of EDS configurations were justified in comparison with evaluations from basic theoretical works of Russian authors. The electromagnetic behaviour of EDS components was simulated using detailed numerical models and original software oriented to parallel computations on multiprocessor platforms. Results of computations were compared to measurements on scaled prototypes and data obtained at Inductrack experiments in the Lawrence Livermore National Laboratory. A desired accuracy of the simulation was demonstrated that proved reliability of the virtual prototyping and enabled scaling of the operational parameters with respect to the power consumption, load capacity, tolerances and other characteristics of real levitated vehicles.

Keywords: magnetic levitation, vehicle, electromagnetic suspension, electrodynamic suspension, hybrid suspension, simulation, prototype, finite elements, computational technique, 3D modelling, magnetic field, eddy current, lifting and drag forces, normalized power, superconducting coil, permanent magnet.

Introduction. In Russia the maglev technologies [1] developed basically in national studies [2-4] have not been implemented into operational transportation systems so far. Meanwhile, maglev transport in China, Korea, Japan, Germany, and other countries is successfully run in service. Practical implementation of the maglev technologies is a response to rapid increase of traffic volume. Advantages of the novel transport are, however, accompanied with a demand for efficient realization to compete economically with conventional wheeled transport. Product and maintenance analyses suggest that commercial maglev projects require high initial investments to guideway structures and

(C) Санкт-Петербургский государственный университет, 2018 
rolling stock. To provide high maglev performance and ensure a cost-effective project with an acceptable payback period, parametric studies and virtual prototyping combined with sub-scale and full-scale testing are the forefront of all design stages.

Efficiency of suspension systems for magnetic levitation has recently progressed with advance in superconductors, magnetic and composite materials, control technology, and power supply. This paper is devoted to the analysis and optimization of electrodynamic suspension (EDS) systems based on a coordinated modelling-and-test approach. Parametric simulations, aimed to identify the system design and operation, are followed with the construction of scaled models and measurements on a test bench to verify the computational models and optimize the design.

A series of detailed 3D numerical models was built for components of EDS. Original computational algorithms and software tools developed for EM simulations of magnet systems in accelerators and tokamaks $[5,6]$ were adapted to maglev studies. The models and computational techniques were verified in comparison of independent simulations with a series of computer codes [7-10], analytical estimations [2-4, 11], and experimental data $[7-10]$.

Parametric simulations were accomplished for over 2000 configurations of the maglev track and onboard magnets, and the speed ranges up to the triple sonic speed. Vectorized parallel computations on a multi-core supercomputer [12] were utilized to retrieve and process data to form a massive database. That enabled optimization of the EDS parameters prior to actual prototyping that resulted in sufficient savings of cost and materials. Such approach has proved to be an efficient and versatile way to mature the design.

The study was aimed to assess the basic operating parameters of the EDS and hybrid suspension configurations [13], evaluate their energy consumption and allowable manufacture tolerances.

Electrodynamic suspension. The electrodynamic suspension technology [2-4], or repulsive levitation, is based on the electromagnetic interaction between a moving magnetic field source and currents induced in a conductive track. Resulting repulsive force lifts the vehicle.

An EDS is characterised by spatial and temporal distributions of magnetic fields, eddy currents, generated heat, and Lorentz forces. These distributions are non-uniform due to geometrical, magnetic, electric, and kinetic parameters of the system [2-4]. To calculate the distributions, detailed 3D computational models [7-10] may be applied. In a simplified way, the repulsive levitation can be described via an integral (resultant) force acting on a field source. In the Cartezian coordinates this force is determined by following components:

1) lift force $F_{z}$, which is counter-directed to the gravity force;

2) drag force $F_{x}$ acting opposite to the speed vector;

3) lateral force $F_{y}$ that causes sideward displacement thus destabilizing the vehicle.

By the magnets, EDS may be divided into two types: with the superconducting magnets (SCM) [2-4] and with permanent magnets (PM), such as the Inductrack system [14-19] that utilizes the Halbach arrays [20]. Previous studies were devoted to electromagnetic analysis of EDS and validation of computational models [7-10]. Figures 1-4 illustrate schematics and FE meshing for two EDS principal concepts: the normalflux system and the null-flux system. The null-flux concept utilizes flux cancellation through the on-board magnet in position with respect to the track structures. This is opposed to the normal-flux concept, where there is no flux cancellation. 


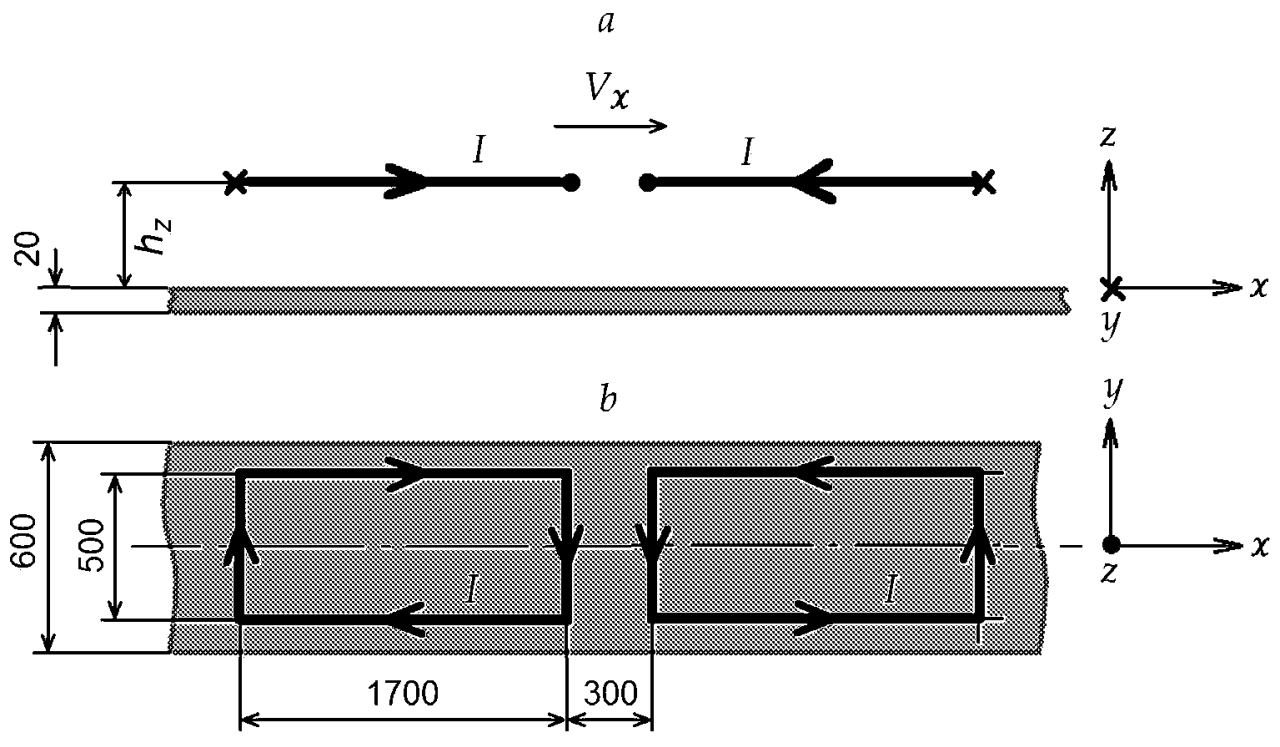

Figure 1. Normal-flux EDS. Suspended SCM is modelled via current loops positioned above continuous aluminium track $a-$ side view; $b-$ top view. Dimensions are given in millimeters.

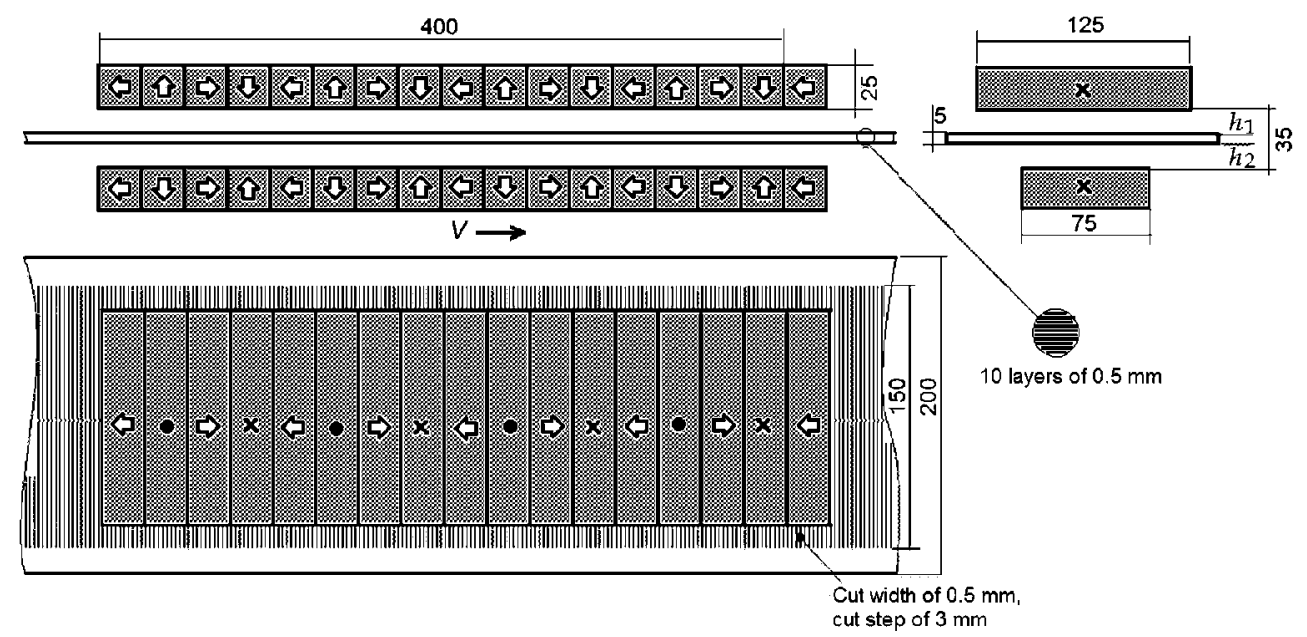

Figure 2. Normal-flux EDS with dual Halbach array of PMs and laminated track Sizes and arrangement correspond to LLNL Test Rig (Livermore, USA) [18].

Dimensions are given in millimeters.

This paper succeeds to the previous studies on suspensions systems for maglev transport [7-10]. Our developments encompass:

- matured numerical technology for analysis of EDS in terms of spatial and temporal variations of the magnetic field, eddy current, Lorentz force density, heat release, and material properties;

- predictive simulations of basic operating modes including abnormal conditions; 


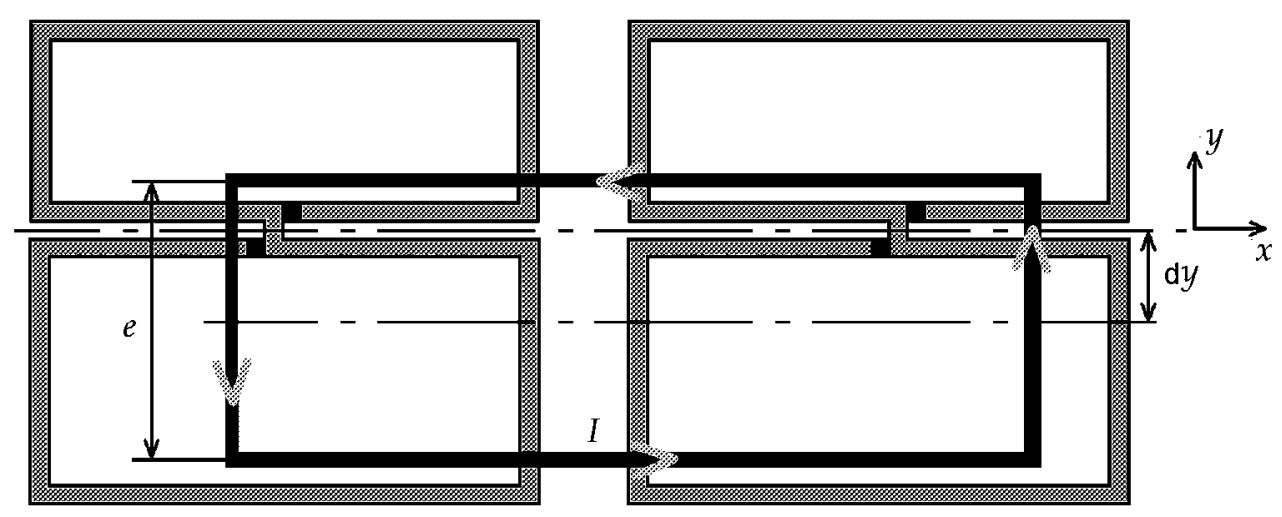

Figure 3. Null-flux EDS with discrete track

Asymmetric double-loop suspension coils are mounted vertically along guideway with shift $\mathrm{d} y<0$ (side view).

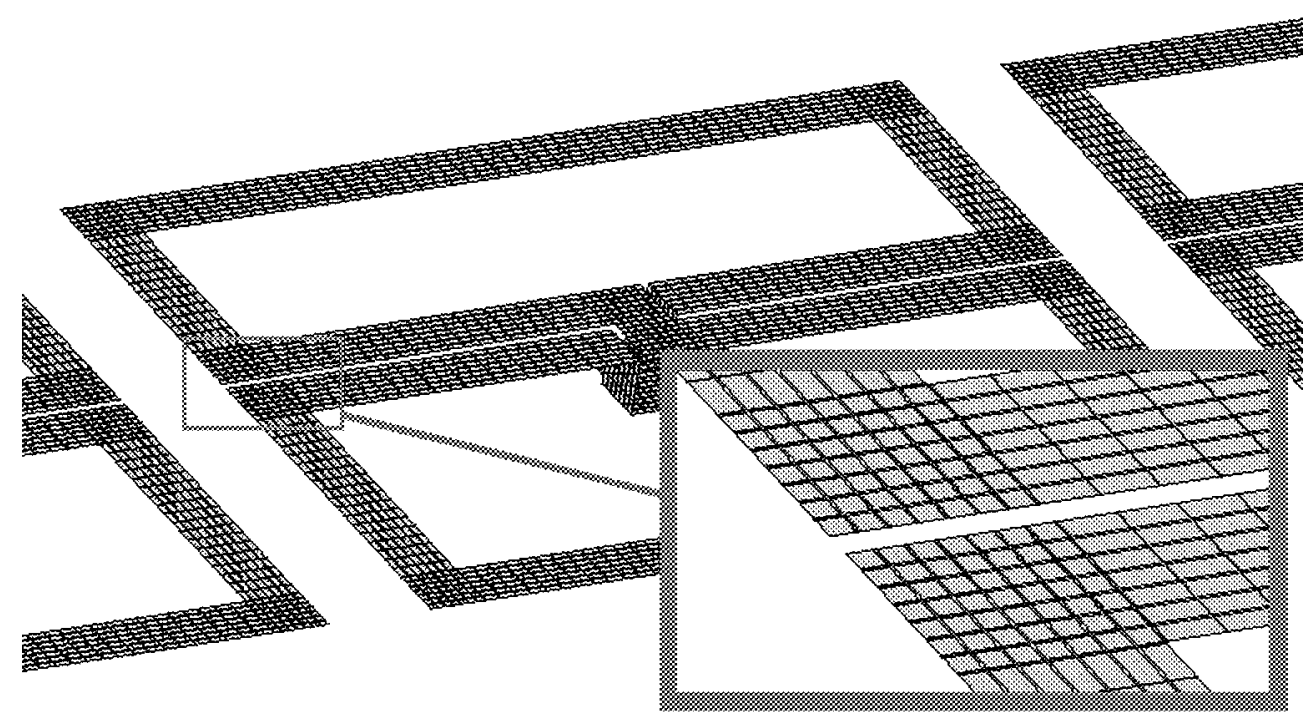

Figure 4. FE model of null-flux EDS with double-loop coils on discrete track Each coil is wound by seven layers.

- numerical modelling with desired accuracy for all types of magnets used in EDS (electromagnets (EM), PM, SCM) individually or in combinations;

- ambient field mapping to ensure the health and ecology safety;

- certified original software (KLONDIKE, TYPHOON, TORNADO, KOMPOT) [21-24] executable on the Russian multi-core supercomputer [12];

- consistent database of simulated EDS parameters and numerical model validated against experiments and analytical estimations [2-4].

As a result, a basis is formed to identify design criteria, configuration and manufacturing tolerances for components of EDS, assign design guidelines, and synthesize an optimized EDS. 
Validation of computational models. Numerical models for basic EDS configurations were validated in comparative simulations with FE codes TYPHOON and TORNADO utilizing different approximations for the solution. A difference between the estimates of the lift and drag forces was found to be below $2.4 \%$ over the operating speed range.

The models of guideway structures were validated in simulations with the codes TYPHOON and KLONDIKE assuming perfect conductivity of the track material. This corresponds to the maximal lift force reached asymptotically with increasing speed. The comparison of results gave the difference as low as $0.2 \%$. This value can be treated as the FE approximation error.

Also, the simulated results were compared [8] with the experimental data obtained at the LLNL Test Rig [18, 19]. The Test Rig (see Fig. 2) was built in the Lawrence Livermore National Laboratory (USA) as a part of the development of the Inductrack technology to check the computer calculations and investigate performance of different laminated track configurations. Figure 5 illustrates a comparison between the data obtained with NIIEFA numerical model [7-9] and LLNL measurements on the Test Rig.

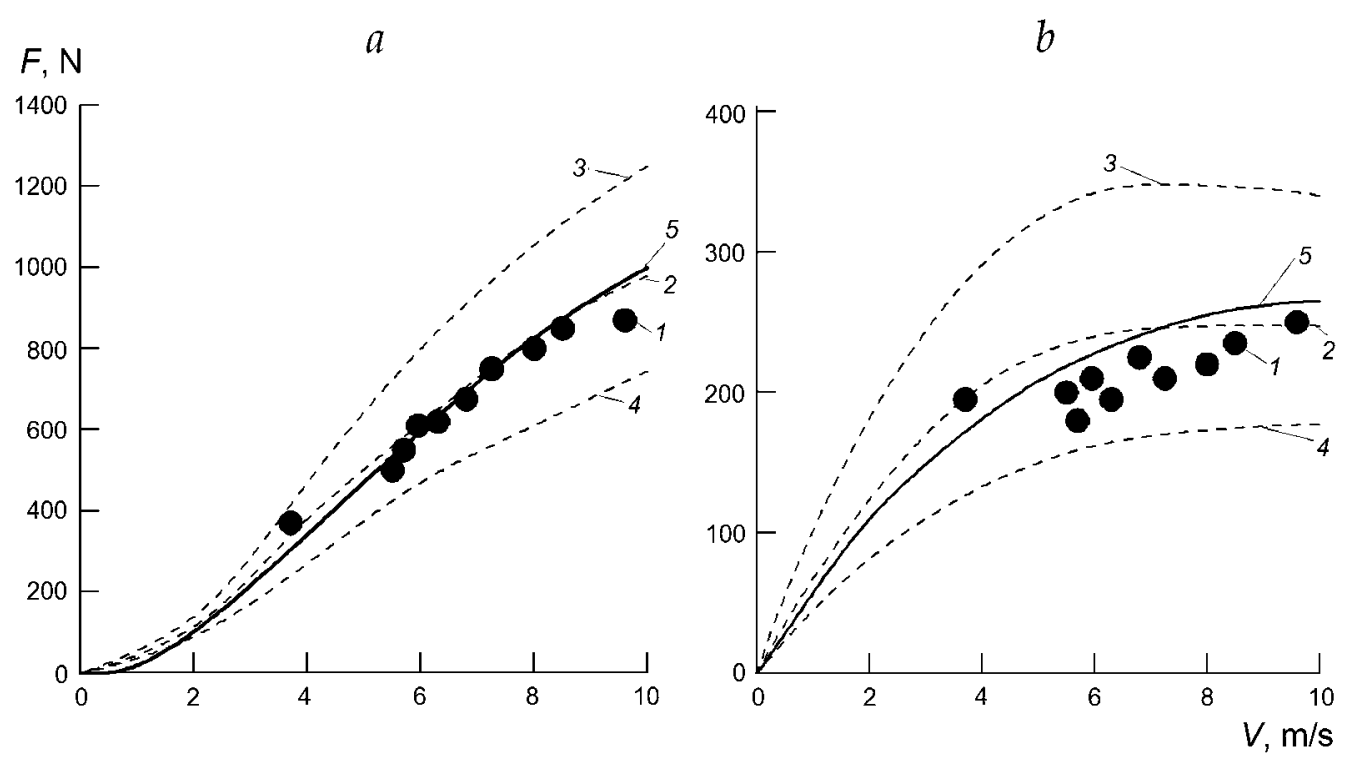

Figure 5. Lift force $(a)$ and drug force $(b)$ vs speed

1 - LLNL experimental data [18]; 2- LLNL simulation for reference position [18];

3, 4- LLNL simulations for $\pm 1 \mathrm{~mm}$ shifted positions [18]; 5 - NIIEFA simulation [7-10].

To conform with the Test Rig parameters, our simulations were limited to a low speed range up to $10 \mathrm{~m} / \mathrm{s}$.

At a middle-to-high speed range the lift force would grow asymptotically approaching a peak value dictated by the EDS configuration. The peak lift force can be determined by solving the nonstationary Cauchy problem for distributed eddy currents or the relevant magnetostatic problem using the method of images.

The numerical analysis has also been supported with measurements on a scaled EDS model with a limited functionality. The model was primarily intended to verify the computational models using results of magnetic measurements on a statically suspended vehicle. Suspension was created by mutual repulsion of two blocks of permanent magnets, 
that imitates the asymptotic behaviour of a PM EDS with a halved lifting gap at infinite speed. Such suspension system is unstable [11] and, therefore, unpractical but suitable for testing.

The virtual prototyping with detailed FE models enable us to escape expensive speedup experiments on a full-scale model, such as direct EM force measurement on a flat freight car. In combination with parametric simulations, the scaled model provides reliable scaling of the simulated operational parameters with respect to the practical load capacity and other characteristics. Such method gives quite accurate and abundant information at a low cost.

The basic electromagnetic parameters and lifting gap of the scaled model were taken similar to those of a real EDS maglev vehicle. The sizes of the suspended platform corresponded to a standard bogie. The distance between the track axes is $1190 \mathrm{~mm}$ that is close to realistic guideways. Experiments on the scaled EDS model were aimed to verify the manufacturing tolerances and check the performance of PM blocks manufactured at NIIEFA for maglev application. Each PM block is formed by an NdFeB PM array sandwiched between two magnetic steel plates. The block is encapsulated in a nonmagnetic stainless steel case. During the experiments the PM block assembly/mounting procedures were adjusted. Also, electromagnetic compatibility of EDS components was tested.

The scaled EDS model was in static suspension for the period of 12 months. Further on, the model and the test bench will be used for long-term operational tests of the instrumentation and control system and estimation of their operating life.

The field map of the scaled EDS model is topologically equivalent to a field distribution of both the PM EDS and SCM EDS. This makes it possible to use the model for studies of SC EDS utilizing high-temperature superconductors (HTSC).

Figures 6, 7 illustrate the scaled EDS model on the test bench.

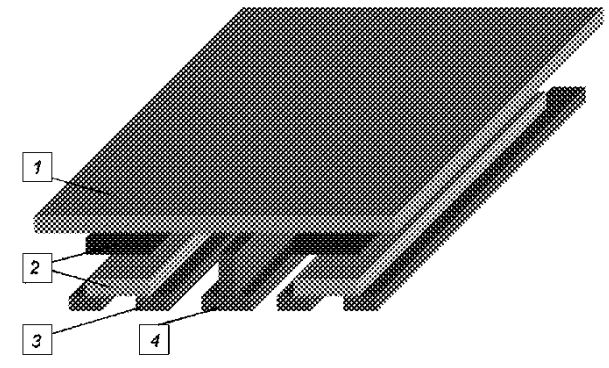

Figure 6. Scaled EDS model 1 - levitated platform; 2- cased PM blocks; 3 - immovable way structure; 4 - tracks.

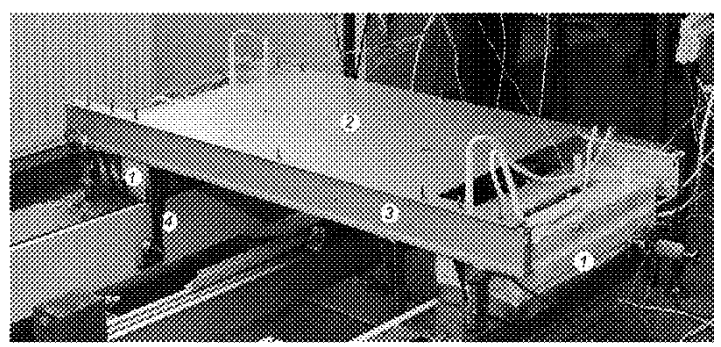

Figure \%. Test of HTSC modules 1 - nitrogen cryostats; 2- levitated platform; 3 - aluminum shapes; 4 - support rollers.

The steel tracks are installed on transverse supports and equipped with cased PM blocks. Measurements are performed with force gauges and air gap sensors. The auxiliary equipment includes a trolley drive mechanism, a sideward displacement compensator, a backlash compensator. The levitated platform can move vertically (along the axis $Z$ ) and horizontally (along the axis $X$ ) at any tilt relative to the tracks. The transverse displacement of the platform (along axis $Y$ ) is limited by the guides.

In the experiments 3 cased PM blocks were mounted on each track. In the reference position the platform was set so that its middle PM blocks were exactly above the middle PM blocks of the tracks. According to the preliminary calculation, the lift force of suspension in the reference position would be much higher than the drag and sideward forces. 
The lift force was measured at different vertical and horizontal positions of the levitated platform. The transverse shift of the platform was eliminated by the sideward displacement compensator. The force gauges with a measuring accuracy of $0.1 \%$ were installed at the platform corners. The air gap between the platform and the tracks was varied with 4 tightening screw.

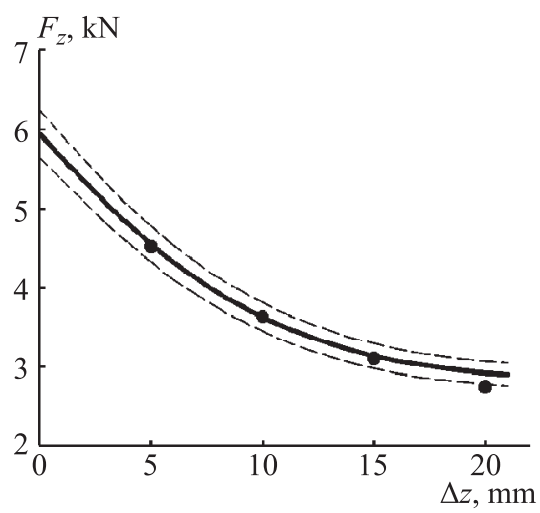

Figure 8. Lift force $F_{z}$ vs air gap $\Delta z$ for scaled EDS model (solid curve calculated results, dots - measurements, dashed curves indicate $\pm 5 \%$ discrepancy about calculated estimate)
The resultant vertical force was determined at each position by summation of the force gauge readings, the total weight of the platform with the cased PM blocks, and the weight of the load placed on the platform. A series of measurements was taken for each air gap size, and the lift force was derived as the mean value. The measurement uncertainty was $2-3 \%$.

Figure 8 presents calculated and measured lift force for the scaled EDS model. The discrepancy between the estimates is as low as $\pm 5 \%$, the maximal difference being occurred at the minimal absolute value of the lift force. Recently, the scaled EDS model was modified by installing 4 cased PM blocks at the levitated platform instead of 3 as in the previous option. The platform can be moved along the tracks within the distance of $1.6 \mathrm{~m}$.

The measured data were compared to the lift force simulated with different numerical models using $4 \mathrm{EM}$ codes [7-10]. The computational models were found to give reliable predictions. This enabled verification of the numerical procedures for scaling operating parameters for practical applications thus making R\&D of real EDS flexible and efficient.

Generalized characteristics of EDS maglev system. When in motion, the value and density of eddy current induced by the suspended magnet in the tracks depend on the magnetic flux in the air gap and the propulsion speed of the maglev vehicle. Further on, for qualitative analysis the track will be approximated as a flat conducting band. The induced eddy current can be described via a closed current loop or a set of such loops using the electrical circuit theory.

Basic concepts of magnetic levitation [2-4] and predictive EM simulations [7-10] lead to the following generalization.

The induced current varies proportionally to the rate of change of the flux in the air gap and inversely to the current loop impedance. As the magnetic flux variations result from the motion of the magnet, emf in the track is proportional to the speed. The current impedance is determined by the ohmic resistance and reactance.

The ohmic resistance $R$ depends on the track material conductivity and the current distribution. Reactance $\omega L$ is a function of the loop self-inductance $L$ and the frequency $\omega$ of the field change. At a low speed, when the effective thickness of the skin layer $[25,26]$ exceeds the track thickness, the ohmic resistance is constant and independent on the propulsion speed. In contrast, the reactance grows linearly with the frequency of the flux change and, therefore, is proportional to the speed. At low speed and low frequency, the main contributor to the impedance is the ohmic resistance. Then, at a steady motion of the levitated magnet along the track, the eddy current amplitude is proportional to the speed. 
With growing speed, the reactance also grows proportionally and dominates in the impedance at high speed. As a result, the linear increase of the eddy current amplitude slows down approaching the asymptote $I_{\max }$.

Being proportional to the eddy current, the lift force exhibits similar behaviour with speed approaching asymptotically its upper margin, as shown in Fig. 9. These curves demonstrate the existence of the "transition speed" [14, 15] for EDS maglev systems, at which the lift force reaches a half of its asymptote regardless of the value of the air gap. As observed, the transition speed is practically independent of the air gap.

The power loss $P$ due to Joule heating in the track is proportional to its resistance and the squared current $P=I^{2} R$. Since the average power $P$ dissipated in the track is given by the product $V \cdot F_{x}$, the drag force can be expressed as $F_{x}=P / V$. At a low speed, we can parametrize the power as $P \sim V^{2}$ and the drag force as $F_{x} \sim V$. At a high speed (at $\left.I \simeq I_{\max }\right)$, the power remains nearly constant

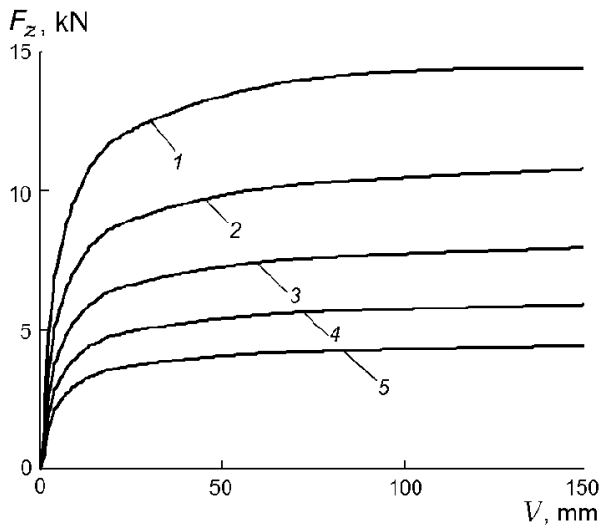

Figure 9. Lift force vs propulsion speed at different air gaps $h$ $1-h=15 \mathrm{~mm} ; 2-h=20 \mathrm{~mm}$; $3-h=25 \mathrm{~mm} ; 4-h=30 \mathrm{~mm}$; $5-h=35 \mathrm{~mm}$.

under the assumption of a constant resistivity of the track. Therefore, $F_{x} \sim 1 / V$. This gives a noted peak of the drag force as shown in Fig. 10. It should be noted that, when the peak is observed, the speed is practically independent of the air gap.

With the skin effect taken into account, resistivity grows at a high speed as $V^{0.5}$, therefore, the drag force is estimated as $F_{x} \sim V^{-0.5}$.

The maglev vehicle dynamics is principally described by the lift-to-drag ratio [2-4]. The drag force reflects the power required to overcome the electrodynamic drag and propel the vehicle. The lift force is attributed to the load capacity. A typical lift-to-drag ratio of an EDS maglev system is illustrated in Fig. 11. As seen, the lift-to-drag ratio (levitation

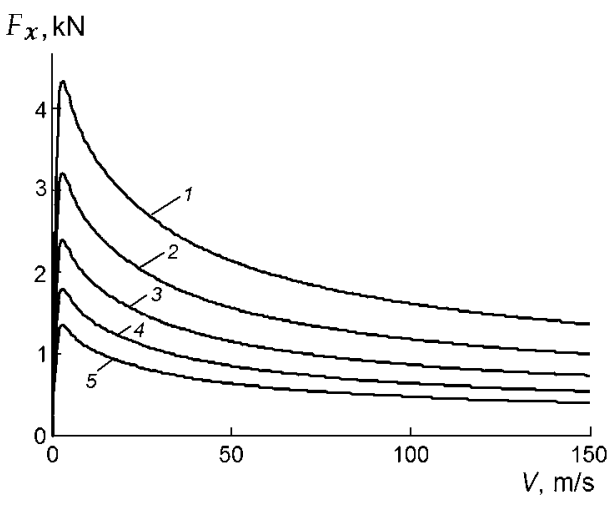

Figure 10. Drag force vs propulsion speed at different air gaps $h$ (see Fig. 9)

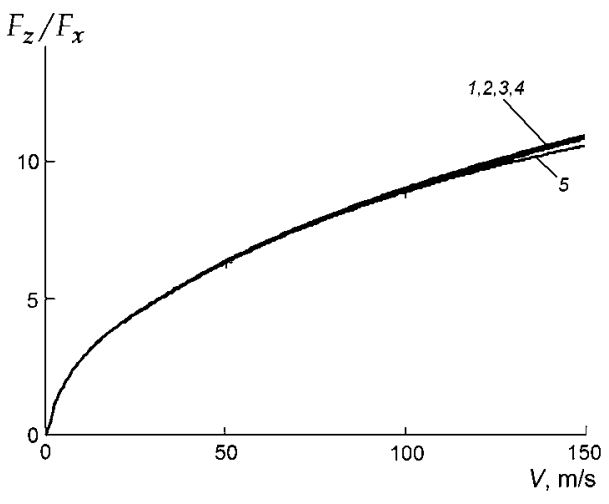

Figure 11. Lift-to-drag ratio vs propulsion speed at different air gaps $h$ (see Fig. 9)

efficiency) increases linearly with increasing speed and practically independent of the air gap. However, the skin effect leads to monotonous grows of the power loss $\left(\sim V^{0.5}\right)$ thus 
worsening the levitation efficiency. Figure 12 shows the power consumption per unit weight load as a function of speed.

For the modelled EDS with flat continuous track and permanent magnets, the power consumption is dictated by the propulsion speed but, in the first approximation, does not depend on the loaded weight. The weight dictates only the air gap at which the lift force and the weight are balanced. Variations of the air gap as a function of speed for different loads are presented in Fig. 13.

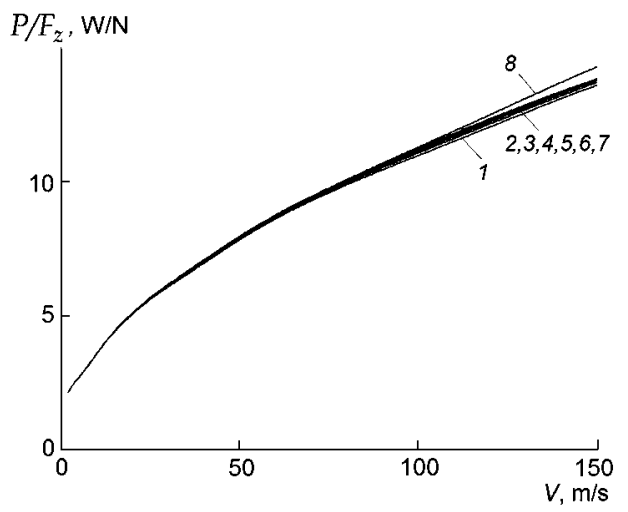

Figure 12. Normalized power consumption vs propulsion speed at different loads $1-15 \mathrm{kN} ; 2-10 \mathrm{kN} ; 3-8 \mathrm{kN} ; 4-7 \mathrm{kN}$ $5-6 \mathrm{kN} ; 6-5 \mathrm{kN} ; 7-4 \mathrm{kN} ; 8-3 \mathrm{kN}$.

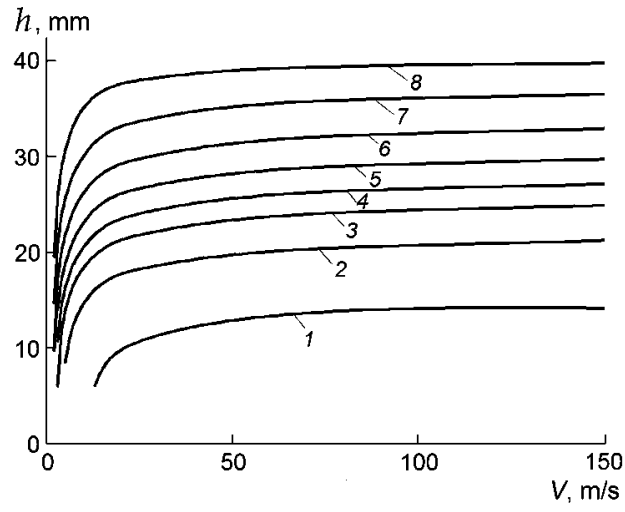

Figure 13. Air gap variation vs propulsion speed at different loads (see Fig. 12)

Evaluation of lift and drag force and linear motor thrust for maglev train. As previously noted, the skin effect is the main reason for non-linear increase of the levitation efficiency with the propulsion speed [8-10]. For the EDS maglev system with Halbach arrays considered and a $20 \mathrm{~mm}$ thick flat aluminum track the skin effect is prominent at the speed over about $3 \mathrm{~m} / \mathrm{s}$. As compared to the SC EDS, the Halbacharray EDS demonstrates a weak dependence of the levitation efficiency on the air gap (see Fig. 11). The lift of the SC EDS (see Fig. 1) reaches its half-maximum at the speed of about $11 \mathrm{~m} / \mathrm{s}$.

Based on the obtained results [7-10], the scaling was made to a realistic flat freight car propelled by a linear induction motor.

The initial parameters were taken as follows:

- operation speed $200 \mathrm{~km} / \mathrm{h}$;

- load condition 50 tons;

- air resistance coefficient $C=0.6$;

- acceleration/slowdown $0.1 \mathrm{~m} / \mathrm{s}^{2}$;

- upward/downward grade 70 or $10 \%$;

- number of bogies 5;

- every bogie is driven with a linear motor module;

- the track and levitation magnet arrangement is shown in Fig. 14;

- EDS configurations under study:

- Option 1. PMs configured in Halbach arrays,

- Option 2. SC racetrack coils $(1500 \times 500 \mathrm{~mm})$,

- Option 3. SC racetrack coils topologically equivalent to the Halbach array. 
The EDS arrangement presented in Fig. 14 corresponds to schematics described in [27]. The guideway tilt of $60^{\circ}$ with respect to the horizontal plane is taken so that to ensure lateral stability.

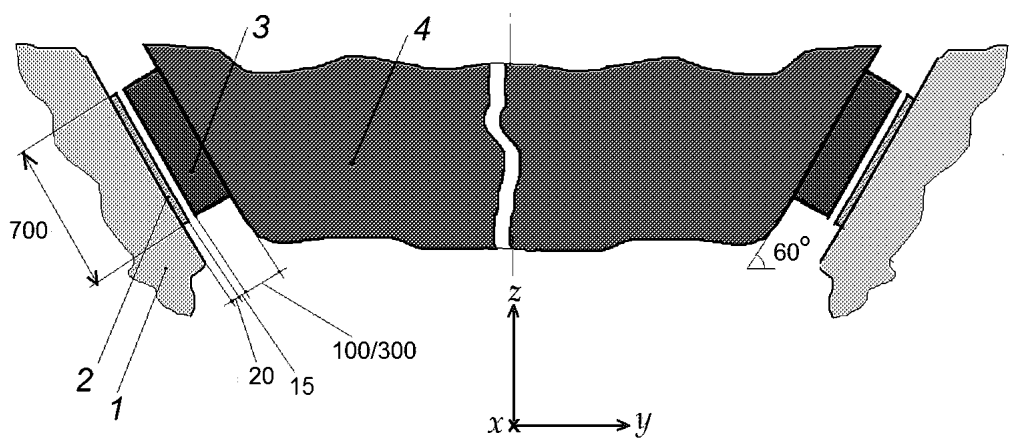

Figure 14. Schematics of EDS maglev car

1 - guideway; 2 - track; 3 - levitation magnet; 4 - bogie. Dimensions are given in millimeters.

A motion scenario from the standstill to the operating speed has been simulated for 3 indicated EDS options. The results include spatial and temporal variations of the magnetic flux, eddy current, Lorentz force, Joule heat and other parameters. Then, evolutions of the integral loads have been calculated for the EDS components. The traction force of a maglev vehicle must be assessed reasoning from the full load condition, acceleration/deceleration, and running resistance. The running resistance includes different components. Evaluations for each type of running resistance are listed in Table 1 . Table 2 presents relevant power consumption.

Table 1. Running resistance and traction force for levitated flat freight car (total weight load $500 \mathrm{kN}$, propulsion speed $200 \mathrm{~km} / \mathrm{h}$ )

\begin{tabular}{|c|c|c|c|}
\hline Running resistance components & $\begin{array}{c}\text { Option } 1 \\
\text { Halbach } \\
\text { array }\end{array}$ & $\begin{array}{l}\text { Option } 2 \mathrm{SC} \\
\text { racetrack coils } \\
1500 \times 500 \mathrm{~mm}\end{array}$ & $\begin{array}{c}\text { Option 3 SC } \\
\text { racetrack coils } \\
\text { (Halbach equivalent) }\end{array}$ \\
\hline & \multicolumn{3}{|c|}{$\mathrm{kN}$} \\
\hline Electrodynamic drag & 150 & 90 & 125 \\
\hline Air dynamic drag & 10 & 10 & 10 \\
\hline Grade resistance $(70 \%$ ) & 37.5 & 37.5 & 37.5 \\
\hline Grade resistance $(10 \%$ o $)$ & 5.36 & 5.36 & 5.36 \\
\hline Acceleration $\left(0.1 \mathrm{~m} / \mathrm{s}^{2}\right)$ & 5 & 5 & 5 \\
\hline Total traction force (grade 70\% ) & 202.5 & 142.5 & 177.5 \\
\hline Total traction force (grade 10\%o) & 170.4 & 110.4 & 145.4 \\
\hline
\end{tabular}

For Option 1, to levitate a loaded flat car of 50 tons the repulsive force of $500 \mathrm{kN} / \cos \left(60^{\circ}\right)=1000 \mathrm{kN}$ should be applied. The lift-to-drag ratio at the speed of $200 \mathrm{~km} / \mathrm{h}$ is near 6.7 , therefore, the electrodynamic drag is determined as $1000 \mathrm{kN} / 6.7=$ $150 \mathrm{kN}$. The normalized power per $1 \mathrm{~kg}$ is $(150 \mathrm{kN} \times 55.5 \mathrm{~m} / \mathrm{s}) / 500 \mathrm{kN}=16.6 \mathrm{~W} / \mathrm{N}$. For the Halbach array the levitation efficiency and the normalized power are the functions of speed and not affected by the air gap size. At any air gap the maximal electrodynamic drag occurs at the speed of nearly $3 \mathrm{~m} / \mathrm{s}$. The levitation efficiency at this speed is evaluated as about 1.3 , the normalized power required to overcome the electromagnetic drag is $4.6 \mathrm{~W} / \mathrm{N}$. Then, the electromagnetic drag at $3 \mathrm{~m} / \mathrm{s}$ is $1000 \mathrm{kN} / 1.3=770 \mathrm{kN}$. 
Table 2. Power predictions for levitated flat freight car

(total load $500 \mathrm{kN}$, propulsion speed $200 \mathrm{~km} / \mathrm{h}$ )

\begin{tabular}{|l|c|c|c|c|c|c|}
\hline \multicolumn{1}{|c|}{ Power consumption } & \multicolumn{2}{|c|}{$\begin{array}{c}\text { Option 1 } \\
\text { Halbach array }\end{array}$} & \multicolumn{2}{c|}{$\begin{array}{c}\text { Option 2 SC } \\
\text { racetrack coils } \\
1500 \times 500 \mathrm{~mm}\end{array}$} & \multicolumn{2}{c|}{$\begin{array}{c}\text { Option 3 SC } \\
\text { racetrack coils } \\
\text { Halbach equivalent) }\end{array}$} \\
\hline & $\mathrm{MW}$ & $\mathrm{kW} /(\mathrm{t} \times \mathrm{km} / \mathrm{h})$ & $\mathrm{MW}$ & $\mathrm{kW} /(\mathrm{t} \times \mathrm{km} / \mathrm{h})$ & $\mathrm{MW}$ & $\mathrm{kW} /(\mathrm{t} \times \mathrm{km} / \mathrm{h})$ \\
\hline Electrodynamic drag & 8.333 & 0.833 & 5.0 & 0.5 & 6.944 & 0.694 \\
\hline Air dynamic drag & 0.556 & 0.056 & 0.556 & 0.056 & 0.556 & 0.056 \\
\hline Grade resistance $(70 \% 0)$ & 2.083 & 0.208 & 2.083 & 0.208 & 2.083 & 0.208 \\
\hline Grade resistance $(10 \% \mathrm{o})$ & 0.298 & 0.03 & 0.298 & 0.03 & 0.298 & 0.03 \\
\hline Acceleration $\left(0.1 \mathrm{~m} / \mathrm{s}^{2}\right)$ & 0.278 & 0.028 & 0.278 & 0.028 & 0.278 & 0.028 \\
\hline $\begin{array}{l}\text { Total traction force } \\
\text { (grade 70\%o) }\end{array}$ & 11.25 & 1.125 & 7.917 & 0.792 & 9.861 & 0.9861 \\
\hline $\begin{array}{l}\text { Total traction force } \\
\text { (grade 10\%o) }\end{array}$ & 9.465 & 0.947 & 6.132 & 0.613 & 8.076 & 0.808 \\
\hline
\end{tabular}

Different numerical models are applied to analyse the null-flux EDS with doubleloop coils [3] and discrete tracks (see Figs 3, 4). One model utilizes the ideal coil approximation with an infinitely thin conductor $[2,3]$. Other models implement the realistic coil configuration or describe CS coils via shorted coils wounded with infinitely thin conductors. The simulated parameters from the idealized model match well the results obtained with the analytical model of infinitely thin conductors $[2,3]$. The idealized model gives a linear increase of the levitation efficiency with speed evaluating it up to about 40 at 50 and 130 at $150 \mathrm{~m} / \mathrm{s}$. The normalized power is found to be as low as nearly $1.2 \mathrm{~W} / \mathrm{N}$ regardless the propulsion speed. The models with realistic coil sizes demonstrate much poorer levitation characteristics. As compared to the idealized coil, the levitation efficiency is found to be 3 to 4 times less at the speed of $50-150 \mathrm{~m} / \mathrm{s}$. Therefore, the power consumed to overcome the electromagnetic drag increases proportionally. The use of a double-loop multiturn coil results in uniformity of the current distribution over the coil cross-section thus increasing the levitation efficiency. For instance, for the double-loop SC EDS concept the power required to compensate the electromagnetic drag and propel a 50 ton vehicle with the speed of $50 \mathrm{~m} / \mathrm{s}$ is about $2.8 \mathrm{MW}$. The calculated efficiency for different track configurations [7-10] is presented in Table 3.

Table 3. Comparative efficiency of EDS maglev with different track concepts (levitated weight $500 \mathrm{kN}$, propulsion speed $200 \mathrm{~km} / \mathrm{h}$ )

\begin{tabular}{|l|c|c|c|c|c|c|}
\hline \multirow{2}{*}{ Track concept } & \multicolumn{3}{|c|}{ Continuous $^{1}$} & \multicolumn{3}{c|}{ Discrete $^{2}$} \\
\cline { 2 - 7 } & $\begin{array}{c}\text { Conduc- } \\
\text { ting } \\
\text { band }\end{array}$ & $\begin{array}{c}\text { Ruther- } \\
\text { ford- } \\
\text { type } \\
\text { cable }\end{array}$ & $\begin{array}{c}\text { Conduc- } \\
\text { ting } \\
\text { band }\end{array}$ & $\begin{array}{c}\text { Infini- } \\
\text { tely } \\
\text { thin } \\
\text { loop }\end{array}$ & $\begin{array}{c}\text { Multiturn } \\
\text { coil with } \\
\text { finite } \\
\text { dimensions }\end{array}$ & $\begin{array}{c}\text { Single-turn } \\
\text { coil with } \\
\text { finite } \\
\text { dimensions }\end{array}$ \\
\hline Levitation magnet type & PM & PM & SC & SC & SC & SC \\
\hline $\begin{array}{l}\text { Power consumed by air } \\
\text { resistance, MW grade up } \\
\text { to 30\%o, acceleration up to } \\
0.1 \mathrm{~m} / \mathrm{s}^{2}\end{array}$ & 1.7 & 1.7 & 1.7 & 1.7 & 1.7 & 1.7 \\
\hline $\begin{array}{l}\text { Power consumed by } \\
\text { electrodynamic drag, MW }\end{array}$ & 8.3 & 2.6 & 5 & 0.6 & 2.8 & 4 \\
\hline Levitation efficiency & 3.4 & 20 & 5.6 & 46 & 10 & 7 \\
\hline Auxiliary power, kW & 0 & 0 & 50 & 50 & 50 & 50 \\
\hline Initial levitation speed, m/s & 3 & 3 & 15 & $\sim 30$ & $\sim 25$ & $\sim 25$ \\
\hline
\end{tabular}

1 Tracks and magnets are tilted by $60^{\circ}$ with respect to the horizontal plane (see Fig. 14) to provide lateral stability.

2 Tracks and magnets are tilted by $90^{\circ}$ with respect to the horizontal plane (see Fig. 3) [2]. 
Conclusions. Comparative calculations have revealed that simplified models, particularly, those neglecting the real coil configuration, underestimate the power consumption of EDS maglev systems. At a low speed range up to $300-400 \mathrm{~km} / \mathrm{h}$, while the power consumed by the electrodynamic drag remains higher than the one of air dynamic drag, that EDS systems prove to be inefficient. A promising solution to improve the maglev levitation characteristics is the use of hybrid suspension systems such as described in patents [28-31]. Such suspension utilizes different types of magnets and is a combination of the EDS and EMS concepts. This enables the best levitation efficiency both at low and high speed ranges.

\section{References}

1. Zaitzev A., Talashkin G., Sokolova Yu. Transport na magnitnom podvese [Maglev transportation]. Saint Petersburg, Saint Petersburg State Transport University Publ., 2010, 160 p. (In Russian)

2. Bakhvalov Yu., Bocharov V., Vinokurov V., Nagorsky V. Transport s magnitnym podvesom [Vehicles with magnetic suspension]. Eds by V. Bocharov, V. Nagorsky. Moscow, Mashinostroenie Publ., 1991, 320 p. (In Russian)

3. Dzenzersky V., Omelyanenko V., Vasiliev S., Matin V., Sergeev S. Vysokoskorostnoj magnitnyj transport s electrodinamicheskoj levitatsiej [High-speed levitating transport with electrodynamic suspension]. Kiev, Naukova dumka Publ., 2001, 482 p. (In Russian)

4. Kim K. Sistemy elektrodvizheniya a ispol'zovaniem magnitnogo podvesa $i$ sverhprovodimosti [Transportation systems employing magnetic suspension and superconducting magnet technology]. Moscow, Educational and Methodological Centre for Rail Transport Technology Publ., 2007,360 p. (In Russian)

5. Glukhih V., Belyakov V., Mineev A. Fiziko-tehnicheskie osnovy upravlyaemogo termoyadernogo sinteza [Applied physics of thermonuclear fusion]. Saint Petersburg, Saint Petersburg Polytechnic University Publ., 2006, 348 p. (In Russian)

6. Amoskov V. M., Arslanova D. N., Bazarov A. M., Baranov G. A., Belov A. V., Belyakov V. A., Belyakova T. F., Vasiliev V. N., Gapionok E. I., Zaitzev A. A., Kaparkova M. V., Kukhtin V. P., Labusov A. N., Lamzin E. A., Larionov M. S., Maximenkova N. A., Mikhailov V. M., Nezhentzev A. N., Rodin I. Yu., Sytchevsky S. E., Firsov A. A., Khokhlov M. V., Shatil N. A. Predictive electromagnetic simulation adapted for maglev railroad system development. VANT. Series Thermonuclear syntesis, 2014, vol. 37, iss. 4, pp. 84-95.

7. Amoskov V. M., Arslanova D. N., Bazarov A. M., Belov A. V., Belyakov V. A., Belyakova T. F., Firsov A. A., Gapionok E. I., Kaparkova M. V., Kukhtin V. P., Lamzin E. A., Larionov M. S., Maximenkova N. A., Mikhailov V. M., Nezhentzev A. N., Ovsyannikov D. A., Ovsyannikov A. D., Rodin I. Yu., Shatil N. A., Sychevsky S. E., Vasiliev V. N., Zaitzev A. A. Simulation of electrodynamic suspension systems for levitating vehicles. I. Modelling of electromagnetic behaviour of maglev vehicles with electrodynamic suspension. Vestnik of Saint Petersburg University. Series 10. Applied Mathematics. Computer Science. Control Processes, 2014, iss. 4, pp. 5-15.

8. Amoskov V. M., Arslanova D. N., Bazarov A. M., Belov A. V., Belyakov V. A., Belyakova T. F., Vasiliev V. N., Gapionok E. I., Zaitzev A. A., Kaparkova M. V., Kukhtin V. P., Lamzin E. A., Larionov M. S., Maximenkova N. A., Mikhailov V. M., Nezhentzev A. N., Ovsyannikov D. A., Ovsyannikov A. D., Rodin I. Yu., Sychevsky S. E., Firsov A. A., Shatil N. A. Simulation of electrodynamic suspension systems for levitating vehicles. II. Validation of computational models. Vestnik of Saint Petersburg University. Series 10. Applied Mathematics. Computer Science. Control Processes, 2015, iss. 2, pp. $18-32$.

9. Amoskov V. M., Arslanova D. N., Bazarov A. M., Belov A. V., Belyakov V. A., Belyakova T. F., Firsov A. A., Gapionok E. I., Kaparkova M. V., Kukhtin V. P., Lamzin E. A., Larionov M. S., Maximenkova N. A., Mikhailov V. M., Nezhentzev A. N., Ovsyannikov D. A., Ovsyannikov A. D., Rodin I. Yu., Shatil N. A., Sychevsky S. E., Vasiliev V. N., Zaitzev A. A. Simulation of electrodynamic suspension systems for levitating vehicles. III. Continuous track systems. Vestnik of Saint Petersburg University. Series 10. Applied Mathematics. Computer Science. Control Processes, 2015, iss. 3, pp. 4-21.

10. Amoskov V. M., Arslanova D. N., Bazarov A. M., Belov A. V., Belyakov V. A., Belyakova T. F., Vasiliev V. N., Gapionok E. I., Zaitzev A. A., Zenkevich M. Yu., Kaparkova M. V., Kukhtin V. P., Lamzin E. A., Larionov M. S., Maximenkova N. A., Mikhailov V. M., Nezhentzev A. N., Ovsyannikov D. A., Ovsyannikov A. D., Rodin I. Yu., Sychevsky S. E., Firsov A. A., Shatil N. A. Simulation of electrodynamic 
suspension systems for levitating vehicles. IV. Discrete track systems. Vestnik of Saint Petersburg University. Series 10. Applied Mathematics. Computer Science. Control Processes, 2016, iss. 3, pp. 4-17.

11. Zhuravlyov Yu. N. Aktivnye magnitnye podshipniki. Teoriya, raschet, primenenie [Magnetic bearings. Theory, calculation, application]. Saint Petersburg, Saint Petersburg Polytechnika Publ., 2003, 204 p. (In Russian)

12. Bartenev Yu. G., Basalov V. G., Vargin A. M., Vyalukhin V. M., Dmitriev N. A., Zhukov D. A., Igrunov V. I., Korzakov V. N., Koshelev V. V., Lashmanov V. N., Logvin Yu. V., Petrik A. N., Selyakin A. G., Semyonov G. P., Stryukov V. N., Ushakov A. Yu., Chaika A. I., Chernykh S. O., Shagaliev R. M., Shatokhin A. V., Shlykov S. N., Shmakov E. L., Yarulin D. R. Multipurpose compact supercomputer. VANT. Series Mathematic modelling of physical processes, 2012, iss. 2, pp. 78-89.

13. Amoskov V., Arslanova D., Baranov G., Bazarov A., Belyakov V., Firsov A., Kaparkova M., Kavin A., Khokhlov M., Kukhtin V., Kuzmenkov V., Labusov A., Lamzin E., Lantzetov A., Larionov M., Nezhentzev A., Ovsyannikov D., Ovsyannikov A., Rodin I., Shatil N., Sytchevsky S., Vasiliev V., Zapretilina E., Zenkevich M. Modelling EMS maglev systems to develop control algorithms. Cybernetics and Physics, 2018, vol. 8, no. 1, pp. 11-17.

14. Post R. F., Ryutov D. D. The Inductrack: A simpler approach to magnetic levitaiton. Livermore, Lawrence Livermore National Laboratory Publ., UCRL-ID-124115, May 1996, 10 p.

15. Post R. F., Ryutov D. D. The Inductrack approach to magnetic levitaiton. Livermore, Lawrence Livermore National Laboratory Publ., UCRL-ID-138593, April 2000, 6 p.

16. Post R. F. Inductrack magnet configuration. U. S. Patent no. 6633217, 2003, 13 p.

17. Post R. F. Laminated track design for Inductrack maglev systems. U. S. Patent no. 6758146, 2004, $12 \mathrm{p}$

18. Hoburg J. F., Post R. F. A laminated track for the Inductrack System. Theory and Experiment. Livermore, Lawrence Livermore National Laboratory Publ., UCRL-CONF-201819, January 2004,5 p.

19. Hoburg J. F., Post R. F. A laminated track for the Inductrack System: Theory and Experiment. 18th Intern. Conference on Magnetically Levitated Systems and Linear Drives. Shanghai, China, October 25-29, 2004, 17 p.

20. Halbach K. Applications of permanent magnets in accelerators and electron storage rings. Journal of Applied Physics, 1985, vol. 57, p. 3605.

21. Amoskov V. M., Belov A. V., Belyakov V. A., Belyakova T. F., Gribov Yu. A., Kukhtin V. P., Lamzin E. A., Sytchevsky S. E. Computation technology based on KOMPOT and KLONDIKE codes for magnetostatic simulations in tokamaks. Plasma Devices Oper., 2008, vol. 16, p. 89.

22. Belov A., Doinikov N., Duke A., Kokotkov V., Korolkov M., Kotov V., Kukhtin V., Lamzin E., Sytchevsky S. Transient electromagnetic analysis in tokamaks using TYPHOON code. Fusion Engineering and Design, 1996, vol. 31, pp. 167-180.

23. Amoskov V., Arslanova D., Belov A., Belyakov V., Belyakova T., Gapionok E., Krylova N., Kukhtin V., Lamzin E., Maximenkova N., Mazul I., Sytchevsky S. Global computational models for EM transient analysis and design optimization of the ITER machine. Fusion Eng. Des., Sept. 2012, vol. 87, pp. 1519-1532.

24. Belov A., Belyakova T., Gornikel I., Kuchinsky V., Kukhtin V., Lamzin E., Semchenkov A., Shatil N., Sytchevsky S. 3D field simulation of complex systems with permanent magnets and excitation coils. IEEE Transactions on Applied Superconductivity, 2008, vol. 18, no. 2, pp. 1609-1612.

25. Tamm I. Fundamentals of the theory of electricity. Moscow, Mir Publ., 1979, $695 \mathrm{p}$.

26. Shneerson G. Polya i perehodnye processy $v$ apparature sverhsil'nyh tokov [Fields and transients in high-power facilities]. Moscow, Energoatomizdat Publ., 1992, 413 p. (In Russian)

27. Koskin Yu. P., Tzeitlin L. A. Sinhronnye mashiny s nemagnitnym rotorom [Synchronous machines with non-magnetic rotor]. Leningrad, Energoatomizdat Publ., 1990, 279 p. (In Russian)

28. Amoskov V. M., Arslanova D. N., Belov A. V., Belyakov V. A., Vasiliev V. N., Glukhih V. A., Zaitzev A. A., Kaparkova M. V., Korotkov V. A., Kukhtin V. P., Lamzin E. A., Larionov M. S., Mikhailov V. M., Nezhentzev A. N., Rodin I. Yu., Sychevsky S. E., Filatov O. G., Firsov A. A., Shatil N. A. Kombinirovannyj magnitnyj podves transportnogo sredstva [Hybrid electromagnetic suspension system for levitated vehicles]. Russian patent no. 2573524, 2014, 14 p. (In Russian)

29. Amoskov V. M., Arslanova D. N., Belov A. V., Belyakov V. A., Vasiliev V. N., Kaparkova M. V., Korotkov V. A., Kukhtin V. P., Lamzin E. A., Larionov M. S., Mikhailov V. M., Nezhentzev A. N., Rodin I. Yu., Sychevsky S. E., Filatov O. G., Firsov A. A., Shatil N. A. Elektromagnitnoe ustrojstvo, puteprovod $i$ transportnoe sredstvo, snabzhennye takim ustrojstvom [An electromagnetic suspension, a track, and a levitated vechicle]. Russian patent no. 2579416, 2014, 29 p. (In Russian)

30. Amoskov V. M., Arslanova D. N., Belov A. V., Belyakov V. A., Vasiliev V. N., Glukhih V. A., Zaitzev A. A., Kaparkova M. V., Korotkov V. A., Kukhtin V. P., Lamzin E. A., Larionov M. S., Mizintzev A. V., Mikhailov V. M., Nezhentzev A. N. , Rodin I. Yu., Sychevsky S. E., Filatov O. G., Firsov A. A., Shatil N. A. Magnitnyj podves transportnogo sredstva dlya kombinirovannogo puteprovoda 
[An electromagnetic suspension system for a combined-type track]. Russian patent no. 2573135, 2014,20 p. (In Russian)

31. Amoskov V. M., Arslanova D. N., Belov A. V., Belyakov V. A., Vasiliev V. N., Kaparkova M. V., Korotkov V. A., Kukhtin V. P., Lamzin E. A., Larionov M. S., Mikhailov V. M., Nezhentzev A. N., Rodin I. Yu., Sychevsky S. E., Filatov O. G., Firsov A. A., Shatil N. A. Sverhprovodyatshee elektromagnitnoe ustrojstvo, magnitnyj podves $i$ transportnoe sredstvo, snabzhennye takim ustrojstvom [A superconductions electromagnetic suspension, a track, and a levitated vechicle]. Russian patent no. 2566507, 2014, 24 p. (In Russian)

Received: August 27, 2018.

Accepted: September 25, 2018.

Author's information:

Victor M. Amoskov - PhD in Physics and Mathematics; sytch@sintez.niiefa.spb.su

Daria N. Arslanova - sytch@sintez.niiefa.spb.su

Alexandr M. Bazarov - sytch@sintez.niiefa.spb.su

Alexandr V. Belov - Leading scientist; sytch@sintez.niiefa.spb.su

Valery A. Belyakov - Dr. Sci. in Physics and Mathematics, Professor; belyakov@sintez.niiefa.spb.su

Alexey A. Firsov - sytch@sintez.niiefa.spb.su

Elena I. Gapionok - sytch@sintez.niiefa.spb.su

Marina V. Kaparkova - sytch@sintez.niiefa.spb.su

Vladimir P. Kukhtin - PhD in Physics and Mathematics; sytch@sintez.niiefa.spb.su

Evgeny A. Lamzin - Dr. Sci. in Physics and Mathematics; sytch@sintez.niiefa.spb.su

Mikhail S. Larionov - sytch@sintez.niiefa.spb.su

Alexandr V. Mizintzev — PhD in Technics; info@nfenergo.ru

Valery M. Mikhailov - sytch@sintez.niiefa.spb.su

Andrey N. Nezhentzev - sytch@sintez.niiefa.spb.su

Dmitrij A. Ovsyannikov - Dr. Sci. in Physics and Mathematics, Professor; dovs45@mail.ru

Alexandr D. Ovsyannikov - PhD in Physics and Mathematics, Assistant Professor; ovc74@mail.ru

Igor Yu. Rodin - PhD in Technics; rodin@sintez.niiefa.spb.su

Nikolay A. Shatil — PhD in Technics; sytch@sintez.niiefa.spb.su

Sergey E. Sytchevsky - Dr. Sci. in Physics and Mathematics; sytch@sintez.niiefa.spb.su

Vyacheslav N. Vasiliev - sytch@sintez.niiefa.spb.su

Margarita Yu. Zenkevich - PhD in Chemistry; m.sorbent@mail.ru

\section{Детальное моделирование электродинамических подвесов магнито-левитационных транспортных систем}

B. М. Амосков ${ }^{1}$, Д. Н. Арсланова ${ }^{1}$, А. М. Базаров ${ }^{1}$, А. В. Белов ${ }^{1}$, В. А. Беляков ${ }^{1,2}$, А. А. Фирсов ${ }^{1}$, Е. И. Гапионок ${ }^{1}$, М. В. Капаркова ${ }^{1}$, В. П. Кухтин ${ }^{1}$, Е. А. Ламзин ${ }^{1}$, М. С. Ларионов ${ }^{1}$, А. В. Мизинцев ${ }^{3}$, В. М. Михайлов ${ }^{1}$, А. Н. Неженцев ${ }^{1}$, Д. А. Овсянников ${ }^{2}$, А. Д. Овсянников ${ }^{2}$, И. Ю. Родин ${ }^{1}$, Н. А. Шатиль ${ }^{1}$, С. Е. Съчевский ${ }^{1,2}$, В. Н. Василъев ${ }^{1}$, М. Ю. Зенкевич

1 АО «НИИЭФА», Российская Федерация, 196641, Санкт-Петербург, Дорога на Металлострой, 3

2 Санкт-Петербургский государственный университет, Российская Федерация, 199034, Санкт-Петербург, Университетская наб., 7-9 
${ }^{3}$ ООО «НИИЭФА-Энерго», Российская Федерация,

196641, Санкт-Петербург, Дорога на Металлострой, 5

4 Академия материально-технического обеспечения им. генерала армии А. В. Хрулёва, Российская Федерация, 199034, Санкт-Петербург, наб. Макарова, 8

Для цитирования: Amoskov V. M., Arslanova D. N., Bazarov A. M., Belov A. V., Belyakov V. A., Firsov A. A., Gapionok E. I. , Kaparkova M. V., Kukhtin V. P., Lamzin E. A., Larionov M. S., Mizintzev A. V., Mikhailov V. M., Nezhentzev A. N., Ovsyannikov D. A., Ovsyannikov A. D., Rodin I. Yu., Shatil N. A., Sytchevsky S. E., Vasiliev V. N., Zenkevich M. Yu. Simulations of maglev EDS performance with detailed numerical models // Вестник Санкт-Петербургского университета. Прикладная математика. Информатика. Процессы управления. 2018. Т. 14. Вып. 4. C. 286-301. https://doi.org/10.21638/11702/spbu10.2018.402

Настоящая статья завершает исследование возможности применения электродинамического подвеса для систем левитационного транспорта. Анализ проводился на базе классических результатов, полученных, в частности, в работах отечественных авторов, и многовариантного детального численного моделирования. Электромагнитные процессы в системах подвеса рассчитывались с использованием оригинального программного обеспечения и вычислительных средств с параллельной архитектурой. Данные численного моделирования совпали с требуемой точностью с результатами измерений на натурных макетах. Использованы как разработанные авторами макеты, близкие по изучаемым параметрам к полномасштабным прототипам, так и данные измерений на макетах в Ливерморской лаборатории (США). Проведенный анализ позволил дать реалистичную оценку затрат электрической мощности, сформулировать требования к магнитным системам подвеса, оценить допуски на точность изготовления и установки элементов систем левитации.

Ключевые слова: магнитная левитация, транспортное средство, электродинамический подвес, электромагнитный подвес, комбинированный подвес, конечные элементы, вычислительная технология, трехмерные модели, электромагнитное поле, вихревые токи, подъемные и тормозящие силы, приведенная мощность, сверхпроводящие катушки, постоянные магниты.

Контактная информация:

Амосков Виктор Михайлович - канд. физ.-мат. наук, вед. науч. сотр.; sytch@sintez.niiefa.spb.su

Арсланова Даръя Николаевна - sytch@sintez.niiefa.spb.su

Базаров Александр Михайлович - sytch@sintez.niiefa.spb.su

Белов Александр Вячеславович - sytch@sintez.niiefa.spb.su

Беляков Валерий Аркадъевич - д-р физ.-мат. наук, гл. научн. сотр.; belyakov@sintez.niiefa.spb.su

Фирсов Алексей Анатольевич - sytch@sintez.niiefa.spb.su

Гапионок Елена Игоревна - sytch@sintez.niiefa.spb.su

Капаркова Марина Викторовна - sytch@sintez.niiefa.spb.su

Кухтин Владимир Петрович - канд. физ.-мат. наук, ст. науч. сотр.; sytch@sintez.niiefa.spb.su

Ламзин Евгений Анатольевич - д-р физ.-мат. наук; sytch@sintez.niiefa.spb.su

Ларионов Михаил Сергеевич - sytch@sintez.niiefa.spb.su

Мизинцев Александр Витальевич - канд. техн. наук; info@nfenergo.ru

Михайлов Валерий Михайлович - sytch@sintez.niiefa.spb.su 
Неженцев Андрей Николаевич - sytch@sintez.niiefa.spb.su

Овсянников Дмитрий Александрович - д-р физ.-мат. наук, проф.; dovs45@mail.ru

Овсянников Александр Дмитриевич - канд. физ.-мат. наук, доц.; ovc74@mail.ru

Родин Игорь Юръевич - канд. техн. наук; rodin@sintez.niiefa.spb.su

Шатиль Николай Александрович - канд. техн. наук, вед. науч. сотр.; sytch@sintez.niiefa.spb.su

Сычевский Сергей Евгенъевич - д-р физ.-мат. наук; sytch@sintez.niiefa.spb.su

Василъев Вячеслав Николаевич - sytch@sintez.niiefa.spb.su

Зенкевич Маргарита Юръевна - канд. хим. наук, ст. науч. сотр.; m.sorbent@mail.ru 